\title{
Physical Security of Water/Wastewater Infrastructure - Planning and Equipment Selection
}

\author{
DRAGOMIR V. MARKOVIĆ, Energoprojekt Entel a.d, New Belgrade \\ RADOJICA M. GRAOVAC, Energoprojekt Entel a.d, New Belgrade \\ Review paper \\ UDC: $628.144-759$ \\ $628.21-759$
}

DOI: 10.5937/tehnikal704612M

\begin{abstract}
This paper discuss why drinking water supply systems and sewerage systems need to be physically protected, what threats should be considered, and points to the necessity of a good knowledge of technological processes in these systems and the possession of information about the essential characteristics of the equipment for the technical security (different physical protective barriers, different alarm systems, access control equipment, intruder detection equipment, optical cables, audio/video equipment, etc.) of the mentioned systems. The approach based on the application of ready-made solutions offered on the market, without prior analysis of the system and the adoption of security plans, is wrong. This paper suggests how to work in order to achieve an optimal solution to the technical protection of the mentioned systems.
\end{abstract}

Key words: water, wastewater, infrastructure, security, equipment, planning

\section{INTRODUCTION}

Water / wastewater systems provide life-important community services to people $24 \mathrm{~h}$ a day, $365(6)$ days a year, and these services are essential to quality and safety of life of the population of each country. Water resources, water / wastewater treatment, transport and distribution facilities are among the critical infrastructures of each country. The rapid development in the field of legislation and practice of water / wastewater infrastructure protection came after the terrorist attack in New York, September 11, 2001. In Serbia, the activities related to water quality protection are developed and world practice is followed.

On the other hand, there are no approaches or definitions regarding the protection of infrastructure, including facilities for water and wastewater, except for general quotes in the Emergency Situations Law, are not sufficiently defined. However, with regard to the EU Critical Infrastructure Directive (Directive 2008/114 / EC), the adoption of the Critical Infrastructure Protection Law can be expected. Together with the Law on Private Security and the standard SRPS

Author's address: Dragomir Marković, Energoprojekt Entel ad, Beograd, Bulevar Mihajla Pupina 12

e-mail: dmarkovic1@ep-enetel.com

Paper received: 06.07.2017.

Paper accepted: 20.07.2017.
A.L2.002: 2015: "Social Security - Private Security Services - Requirements and Instructions for Conformity Assessment", this will open approaches for adoption of by-laws and instructions for public water management and communal Companies how to plan physical and technical security [1]. In Serbia, the largest number of water infrastructure facilities is without technical protection equipment, while a smaller number of facilities are equipped with technical protection devices according to the technical solutions of the manufacturer or solutions have been applied as for the protection of general public facilities, mostly by using CCTV cameras. For only a small number of facilities, an elaborate of security analysis with the proposal of the equipment, had been made first, and on that basis equipment for technical security have been selected, contracted and installed.In this paper general approaches in evaluation of the security risk for water infrastructure facilities, with the emphasis on the sources, wells and pumping plants, planning guidelines, overview of the characteristics and possibilities of technical protection equipment, based on the global practice and concrete experiences from some of the countries of the Middle East is described.

\section{ANALYSIS OF RISK AND THREATS FOR WATER INFRASTRUCTURE}

The mostly reported mistakes in the operation of water infrastructure are grouped as: loss of water 
pressure in most of the water supply system, loss of water supply over a longer time interval as a result of the termination of treatment or distribution of water, catastrophic use or theft of chemicals for water treatment which has a direct impact on public health, deliberate contamination of water or contamination as a result of an incident on the water supply system resulting in an impact on public health, longer periods of absence of treatment and collection of wastewater, use of wastewater at collection sites as a means of attacking other water infrastructure facilities.

The risks and threats that may manifest on the operation of water infrastructure facilities are the following:

Risks due to natural disasters: earthquakes, floods, strong winds, risk of worker disease (pandemic), risk of retirement of employees who led the production process Infrastructure errors.

Threats to the water management system can be those that come from outside (sabotage, vandalism), those generated within a water management organization (employees dissatisfied with their status, failure to comply with technical protection procedures) and threats that arise as a result of incidents of uncontrolled access to facilities or frustrated activists. These threats can be further categorized as threats of low, medium and high levels.

It is necessary for each water management facility to undertake risk and threat assessments and on the basis of this, to make a plan of technical protection of the facility, or to plan the appropriate technical means. When assessing risks, it is necessary to identify categories of persons who would perform unauthorized access to a water facility in order to stop the processing and distribution of water or contaminate water, or make a malicious act. The category of people potentially threatening critical infrastructure is defined as: vandals, criminals, saboteurs (or terrorists) and insiders.

It is necessary to create a threat matrix as well as an assessment table for the application of certain technical means for each plant / structure / object of the water infrastructure facilities.

\section{BASIC ROLE OF PHYSICAL PROTECTION EQUIPMENT}

Physical protection systems should ensure the effective implementation of the following measures [26]:

Deterrence from access to the infrastructure are measures through providing lighting facilities, prominent and fully visible video surveillance cameras, fully visible infrastructure facilities with no visible obstacles, visible presence of staff, etc.

Detection, under detection, is assumed security measures intended to detect the presence of a person accessing an object without the permission and knowledge of operational personnel of water facilities.

Delay, are measures to set physical barriers so that the intruder (or intruders) that have already entered the zone of the protected object and which is covered by the detection measures slows down on the path of advancement towards the ultimate goal-protected object for the purpose of coming of the physical protection team.

Response, means the response of the physical protection team in terms of stopping an intruder whose presence is detected in the protected zone of water objects. Figure 1 gives an illustrative overview of the above measures or activities, and Table 1 shows the calculation of individual time intervals.

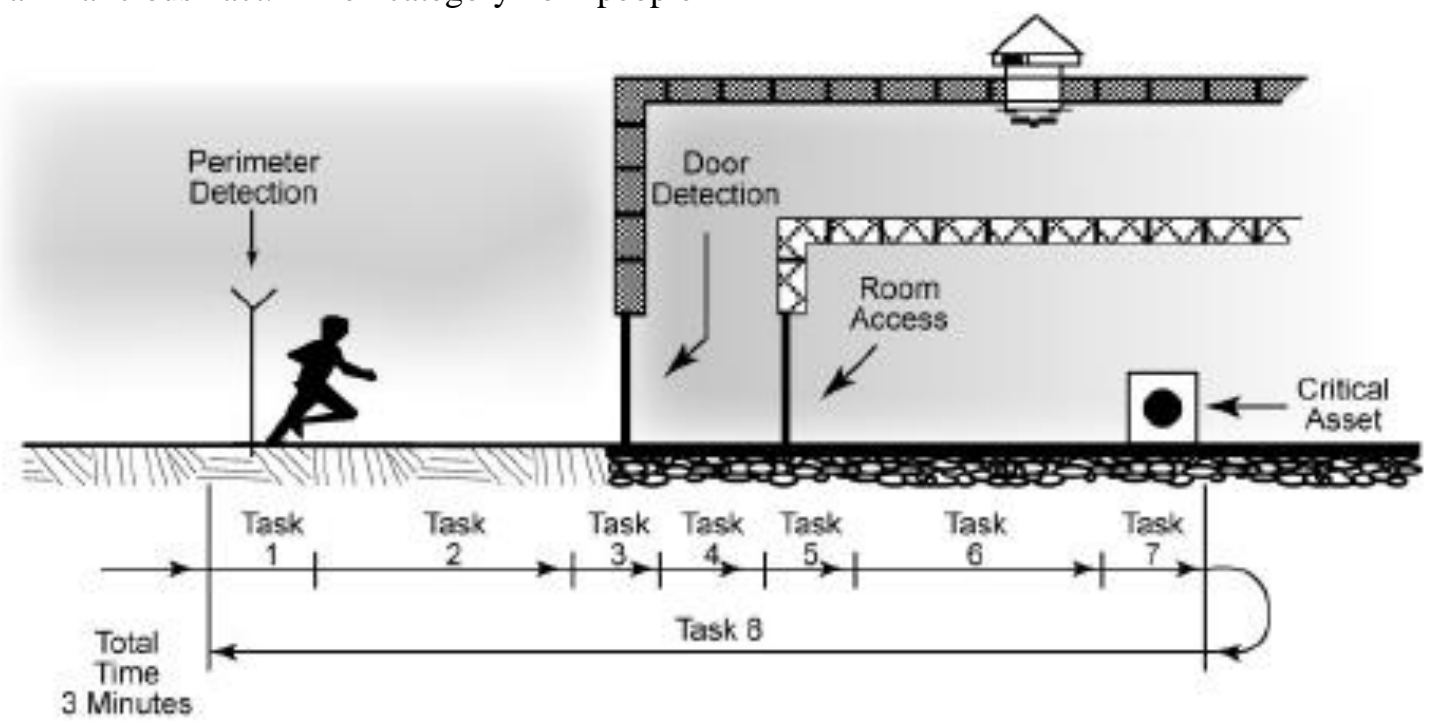

Figure 1 - Criminal activities during access to a water facility 


\section{SELECTION OF PHYSICAL PROTECTION EQUIPMENT}

An example of physical equipment selection for water wells and pumping stations is shown below [29]. Security measures in terms of delay of access to the facility are:

At the level of the fence or perimeter of the plant:

Delay - It is possible to plan: the standard fencewall around the plant; reinforced wall or reinforced fence; the special foundation of the fence-wall against digging; a massive obstacle at the entrances to protect access to the facility by larger vehicles; padlocks at the entrance gates; the protection of steel grids of all gaps or passages at the perimeter of the plant.

Detection - It is possible to plan: a perimeter detection system; electronic control of passage through the gate (this is also a system of delay); illumination of perimeter; illumination of entrance gates.

Table 1. Calculation of activity extensions for unauthorized access to a water facility

\begin{tabular}{|l|l|l|l|l|}
\hline Activity & $\begin{array}{l}\text { Task } \\
\text { Time(minutes) }\end{array}$ & $\begin{array}{l}\text { Cumulative Time } \\
\text { (minutes) }\end{array}$ & $\begin{array}{l}\text { Adversary Task } \\
\text { description }\end{array}$ & Response \\
\hline 1 & 0.1 & & Climb over fence & $1^{\text {st }}$ Alarm \\
\hline 2 & 0.3 & 0.4 & Run $80 \mathrm{M}$ & \\
\hline 3 & 0.8 & 1.2 & Force door & $2^{\text {nd }}$ Alarm \\
\hline 4 & 0.4 & 1.6 & Walk $45 \mathrm{M}$ & \\
\hline 5 & 0.2 & 1.8 & Cut door lock & \\
\hline 6 & 0.1 & 1.9 & Walk to asset & Response Force Arrives \\
\hline 7 & 0.2 & 2.1 & Disable asset & Stop Adversary \\
\hline 8 & 0.9 & 3.0 & Escape & \\
\hline & 3.0 & & Total Time & \\
\hline
\end{tabular}

\section{a) Within plant, between the fence and the protected object}

Delay - It is possible to plan: the next fence-wall; reinforced fence-wall; special foundation for fencewall against digging; massive obstacles to protect access to the facility; padlocks at the entrance gates of the next fence; protection of feeder substations with an additional fence-network; protection of diesel aggregates with additional fence-network; locks and padlocks on the door of a chemical store; shafts with reinforcement and locking system.

Detection - It is possible to plan: a detection system on another fence; electronic control of entry into the warehouse of chemicals; electronic control of passage through the gate (this is also a system of delay); electronic detection of unlocking of padlock on shaft covers; arranging the terrain between the enclosure and the protected object so that the access to the object is completely visible or makes it impossible to access the protected object and that the intruder is not noticed.

\section{b) At the level of a protected object}

Delay - It is possible to plan: installation of protective covers over the source / well and pipes that come out of the source / well; installation of protective cages around the entire source / well and pipes that come out of the source and are located nearby; protection of the covers of all valves; the installation of doors where it is not possible to remove hinges or to remove the door and which are secured by a lock; equipping the locks with the key of all the front doors; installation of explosion-proof exterior doors; setting obstacles for vehicles at the entrance gates; installation of bulletproof windows on the windows; placing a protective lattice on blinds or louvers; setting pads on all openings for exit to the roof; protection of internal transformers, diesel generators and electric distribution plants by placing it in cages with padlock-key; access under the key for the chemical line.

Detection - It is possible to plan: a detection system for access to main valves; an external door fitted with open-closed indication; electronic access for the front door; double entry doors equipped with a doorentry system (so-called door trap); glass breakers detectors on windows; detectors of persons moving within the space; additional gratings on the louver and grill openings with detection of passage; protection of the stairs for the roof with an obstacle and with the detection of passage through the stairs; locked access to an 
external line for the addition of chemicals with the detection of access to the line; locked access to an internal line for the addition of chemicals with the detection of access to the line.

\section{c) Water quality control system}

It is possible to plan the detection of unauthorized access to the system for "on-line" water quality detection.

\section{d) Video surveillance with fixed type CCTV cameras}

It is possible for these cameras to be set up for video surveillance: of all external doorways; all covers and shutters on the shafts and valves. Selecting the number and quality of the camera as well as determining the position can be made to allow: Observation (the size of the display of the person or vehicle being watched should be $5 \%$ of the height of the monitor): detection: (the size of the display of the person or vehicle being viewed to be $10 \%$ of the monitor height): Recognition: (the size of the view of the person or vehicle being watched should be $50 \%$ of the monitor height): identification (the size of the display of the person or vehicle being watched should be $120 \%$ of the supervisory monitor height), envisage local recording and remote alarming.

\section{e) CCTV surveillance with motorized rotating cameras and motorized zoom capability (optical zoom)}

It is possible to install these cameras for surveillance of: the main gate with identification of vehicle registration plates; main entrance doors; complete video surveillance of the perimeter of the facility; interior spaces, with the application of the above principles in the selection and positioning of cameras as well as local recording and remote alarming.

\section{f) Electrical equipment supply and cabling methods}

It is possible to plan: that all electric cabinets shall be equipped with key locks or padlocks; that the power supply of the equipment is so-called uninterruptible power supply (UPS); that the complete electrical installation will be carried out in pipes or below the plaster with spare routes for the technical protection system.

\section{g) Equipment for operating wells and pumps - SCADA}

It is possible to ensure that PLC cabinets are equipped with: key lock or padlock; special switches with contacts indicating that the door of the cabinet is open by force; that the complete wiring from the PLC to all encoders and measuring instruments on the well or to the pump is carried out in pipes so as to prevent direct access to the cables.

\section{CONCLUSION}

Certainly the preparation of the elaborate with the analysis of security risks and threats is an important step in the planning of physical protection for water / wastewater infrastructure. After that, it is possible to see the optimal solution and the choice of technical protection equipment and in order to achieve the goal of reducing these risks and threats. The author's intention was to present the basic approaches to the selection of this equipment, which can certainly help to review this issue by those who make decisions on investments for the construction or rebuilding of water infrastructure facilities.

\section{REFERENCES}

[1] Jakovljević V. Legislation and practice of protection of critical infrastructure of Serbia, Proc. of International Conference - Resilience of Critical Infrastructure Protection in Europe (RECIPE), 2015.

[2] Physical security technologies for Water and Waste Water Utilities, AWWA Research Foundation, USA, 2008.

[3] Guidelines for the Physical Security of Water Utilities, ASCE/AWWA Draft American National Standard for Trial Use, December 2006.

[4] Copeland C. Terrorism and Security Issues Facing the Water Infrastructure Sector, CRS Report for Congress, USA, December 15, 2010.

[5] Hopkins B. State Official's Guide to Critical Infrastructure Protection, 88 p., The Council of State Governments, USA, 2003.

[6] Critical Infrastructure Protection: Threats, Attacks and Counter measurements, TENACE, March 2014.

[7] Van Leuven LJ. Water/Wastewater Infrastructure Security: Threats and Vulnerabilities, in Robert M. Clark, Simon Hakim, Avi Ostfeld (Ed.), Handbook of water and wastewater systems protection, Ch. 2, 528 p., New York : Springer, 2011.

[8] Plan To Counter The Threats To Municipal Water Supply and Water Reservoirs, National Disaster Management Authority, Government of India, 73 p., July, 2010.

[9] Different security projects for water plants in the Middle East, Energoprojet Entel. 


\section{REZIME}

\section{TEHNIČKA ZAŠTITA INFRASTRUKTURE ZA VODU/OTPADNU VODU - PLANIRANJE I IZBOR OPREME}

U ovom radu se razmatra zašto bi vodovodni i kanalizacioni sistemi trebalo da budu tehnički zaštićeni, koje pretnje treba uzeti u obzir, $i$ ukazuje na neophodnost dobrog poznavanja tehnoloških procesa $u$ ovim sistemima i posedovanja informacija o bitnim karakteristikama opreme za tehničko obezbeđenje (različite fizičke zaštitne barijere, različiti alarmni sistemi, oprema za kontrolu pristupa, oprema za detekciju uljeza, optički kablovi, audio / video oprema itd.) pomenutih sistema. Pristup zasnovan na primeni gotovih rešenja koja se nude na tržištu, bez prethodne analize sistema i donošenja bezbednosnih planova, je pogrešan. Ovaj rad sugeriše na koji način treba da se radi da bi se došlo do optimalnog rešenja tehničke zaštite posmatranih sistema.

Ključne reči: voda, otpadna voda, infrastrultura, zaštita, oprema, planiranje 